\title{
Digitalisering i \\ helsevesenet skaper nye roller for sykepleier og pasient
}

Det er ikke nødvendigvis en motsetning mellom «varme hender» og «kald teknologi».

Silje Stangeland Lie

Førsteamanuensis

Fakultet for helsefag, VID vitenskapelige høgskole, Sandnes

Sykepleier-pasient-relasjonen

Sykepleierrollen

Sykepleien 2019107 (78902) (e-78902)

DOI: 10.4220/Sykepleiens.2019.78902

\section{Hovedbudskap}

Nye måter å utøve sykepleie på blir muliggjort i vår digitale verden. Dette krever formell forberedelse, opplæring og ny kompetanse, både blant sykepleiere og pasienter. Grundig opplæring er en forutsetning for at man skal kunne utnytte teknologien på en best mulig måte til å st øtte sykepleier-pasient-relasjonen. 
Avansert medisinsk teknologi, digitale innovasjoner og digital kommunikasjon er i stadig større grad nødvendig for å sikre god kvalitet i helsetjenestene. Digitaliseringen av helsetjenestene er ikke noe vi som helsepersonell kan velge om vi vil være en del av eller ikke. Utviklingen og endringene er rotfestet både politisk og i samfunnet for фvrig (1-3). Ikke bare politiske mål og virkemidler, men også befolkningens og helsevesenets $\varnothing$ nsker og behov, forutsetter en endring til en digital helsetjeneste $(4,5)$.

Digitale helsetjenester er dynamiske, etter som teknologien endres og forbedres. Digitale helsetjenester kan potensielt forandre rollene til aktørene i det tradisjonelle helsevesenet. Digitaliseringen kan bringe pasienten nærmere sykepleieren, men man kan også se for seg at denne utviklingen kan øke det relasjonelle gapet mellom disse.

\section{Sykepleie i en digital helsetjeneste}

Internett og elektroniske verktøy kan påvirke kommunikasjonen og dermed relasjonene både negativt og positivt. Når vi oppnår noe på grunn av teknologi, kan vi risikere å miste noe annet. Tidligere forskning har vist at den digitale verdenens inntog i helsevesenet har skapt en lang rekke utfordringer, blant annet for relasjonen mellom sykepleier og pasient $(6,7)$.

\section{三 «Digitale helsetjenester kan potensielt forandre rollene til aktørene i det tradisjonelle helsevesenet.»}

Det finnes per dags dato en god del forskning som vurderer fordeler og ulemper ved digitale helsetjenester og hvordan pasienter opplever slike tjenester $(5,8-15)$. Likevel er det fremdeles behov for å reflektere over noen spesifikke aspekter av sykepleie i en digital helsetjeneste. Dette gjelder blant annet profesjonell kommunikasjon gjennom digital teknologi, det å tilpasse sykepleie til bruk av teknologi og det å bli kjent med pasientene og bygge relasjoner gjennom digital teknologi (16).

Hensikten med denne fagartikkelen er derfor å diskutere hvordan vi kan forstå sykepleier-pasient-relasjonen i en digital verden. 


\section{Bakgrunn og definisjon av begreper}

Sykepleier-pasient-relasjonen eksisterer primært for å møte pasientens behov for helsetjenester (17).

Begrepet «personsentrert omsorg» har de senere årene fått mye oppmerksomhet i helselitteraturen og helseforskningen. Personsentrert omsorg henger sammen med myndiggjøring (empowerment), altså det å støtte pasienters og brukeres autonomi samt å respektere hver enkelt persons verdier, vurderinger og daglige valg (18).

Mange helseforskere bruker i dag konseptet personsentrert omsorg som en indikator på om interaksjonen og forholdet mellom sykepleiere og pasienter har god kvalitet (19). Personsentrert sykepleie innebærer blant annet å involvere pasientene i et partnerskap, i fellesskap å bli enige om behandlingsmål eller eventuelt å fokusere på pasientens egne mål, og sist, men ikke minst å kommunisere godt (20).

\section{Vekk fra en hierarkisk tilnærming}

Tradisjonelt må vi kunne si at tilnærmingen i helsetjenestene har vært basert på en mer autoritær interaksjon mellom helsepersonell og pasient. Kommunikasjonen har i denne hierarkiske tilnærmingen vært basert på en antakelse om helsepersonellets kompetanse og fagansvar, og en forventning om pasientenes såkalte compliance.

Endringen til en personsentrert omsorg har sprunget ut av en misnøye med den biomedisinske modellen og det medfølgende asymmetriske maktforholdet mellom partene. Personsentrert omsorg som tilnærming legemliggjør et komplekst sett av profesjonelle, sosiologiske og politiske ideer om forholdet mellom helsepersonell og pasient som et forhold mellom likeverdige partnere (20).

\section{三 «I dagens helse- og omsorgstjenester klarer kanskje ikke den enkelte sykepleieren å møte alle de komplekse behovene pasientene har.»}

Det å overføre idealet om personsentrert omsorg til konkret klinisk praksis kan være utfordrende (18). I dagens helse- og omsorgstjenester klarer kanskje ikke den enkelte sykepleieren å møte alle de komplekse behovene pasientene har. 
Krav til kvalitet, pasientsikkerhet, effektivitet og omfattende behandling krever at relevante profesjonelle og organisatoriske ressurser blir samlet rundt hver enkelt pasient. Kan innovasjoner fra den digitale verdenen og et digitalt helsevesen bidra til å fasilitere dette på en hensiktsmessig måte?

\section{Digitale systemers hegemoni}

Den digitale verdenen defineres her som konteksten vår, altså den verdenen vi lever i per i dag. Egentlig er det å definere den digitale verdenen like vanskelig som å gi en på forhånd fastsatt definisjon av størrelsen på et hus eller lengden av et tau: Det kommer an på hvert enkelt hus, hvert enkelt tau. Og definisjonen vil hele tiden endres som et resultat av videre teknologisk utvikling.

Likevel kan man vel beskrive den digitale verdenen som tilgjengeligheten og bruken av digitale verktøy for å kommunisere via internett, digitalt utstyr, smartteknologi og andre teknologier.

«Digital verden» er et uttrykk som synliggjør hegemoniet til digitale systemer og teknologi i vårt nåværende samfunn (21). Utrykket «digitalisering» handler hovedsakelig om den konkrete teknologien, men den digitale verdenen omfatter oss som borgere, forbrukere og pasienter, og hvordan vi tar i bruk digitaliseringen.

\section{Pasientens helsetjeneste}

Bent Høie lanserte i 2014 begrepet «pasientens helsetjeneste» og markerte på den måten en planlagt endring i norsk helsepolitikk. Denne endringen blir omtalt i flere politiske dokumenter, blant annet i NOU-en Innovasjon i omsorg fra 2011 (22). Her beskrives behovet for nye og innovative måter å jobbe på i den norske helsetjenesten for å imøtekomme behovene til nye generasjoner pasienter og pårørende.

Dette synes nødvendig, da forbedringer i medisinsk behandling kombinert med $\varnothing \mathrm{kt}$ levealder i befolkningen gjør at mange pasienter lever i mange år med kroniske sykdommer og tilstander. De lever gjerne også «friskere» liv, det vil si mindre preget av sykdommen eller tilstanden de har. 
Mange mennesker som mottar helsetjenester, lever hjemme og trenger ikke nødvendigvis slik omfattende pleie som svært syke eller døende pasienter gjorde på 1800-tallet, da sykepleie som profesjonelt yrke oppsto. Dette gjør at dagens borgere har andre behov og andre forventninger til helsetjenestene.

I Norge satses det på både e-helse og velferdsteknologiske løsninger. Dette fremkommer av flere politiske dokumenter som er henvist til tidligere, og ikke minst av opprettelsen av Direktoratet for e-helse, Nasjonalt senter for e-helseforskning med mer $(1,22)$. Sammen viser alt dette at både personsentrert sykepleie og innovasjon i helsetjenestene er et hovedområde.

\section{Diskusjon}

Den teknologiske utviklingen vi opplever i verden, er ekstrem. Utviklingen innebærer at sykepleiere må bruke ny teknologi og nye digitale verktøy for å fremme helse og for å observere og skaffe informasjon når de tilbyr helsetjenester og kommuniserer med sine pasienter.

Dette endrer måten sykepleie utføres på, og innholdet i sykepleier-pasient-relasjonen. Digitale plattformer som er tilgjengelige i dag, er i realiteten endimensjonale, og dermed forsvinner noen av de elementene som sykepleiere tidligere kunne bruke sine sanser til å få informasjon om. Dette kan dreie seg om lukt, hørselsinntrykk, følelser og synsinntrykk, for å nevne noe.

\section{$\equiv$ 三Digitale plattformer er i realiteten endimensjonale.»}

Dermed gir den digitale verdenen både nye muligheter og nye utfordringer knyttet til det å innhente informasjon og å møte pasientens helsepersonellbehov, som i hovedsak er formålet med sykepleierens pasientforhold.

På den ene siden kan denne utviklingen $\varnothing$ ke effektiviteten, pasientsikkerheten og den personsentrerte omsorgen, og redusere pasientenes behov for å reise til institusjoner, og $\mathrm{i}$ tillegg utvide den tiden de eldre eller de funksjonshemmede kan leve i sine egne hjem. Alt dette er i tråd med politiske føringer og målsettinger. 
På den andre siden, og selv om teknologien kan omdefinere noen aspekter av sykepleierens forhold til sine pasienter, synes andre aspekter fortsatt å være like viktige. Dette kan for eksempel dreie seg om behovet for åpenhet og tillit $\mathrm{i}$ relasjonen og kommunikasjonen (23).

\section{Teknologiens viktigste historiske bidrag}

Kanskje vil innholdet i relasjonen mellom sykepleier og pasient ikke endres så mye, selv om måten kommunikasjonen gjennomføres på, endres i lys av den skiftende konteksten og utviklingen av nye digitale verkt $\varnothing y$ og kommunikasjonsmetoder? Kanskje betyr all den nye teknologien at tillit i relasjonen mellom sykepleier og pasient nå vil bli enda viktigere enn noensinne?

\section{三 «Det handler om at sykepleiere bruker teknologien slik den bør brukes: til det beste for pasienter og brukere.»}

Det er ikke nødvendigvis en motsetning mellom «varme hender» og «kald teknologi» (24). Det å ta i bruk internett og tilby pleie og omsorg også i virtuelle miljøer og inn i pasientenes hjem vil kunne være en av teknologiens viktigste historiske bidrag til sykepleie for pasientenes beste (25). Det handler ikke om teknologi versus omsorg og pleie, det handler om at sykepleiere (og annet helsepersonell) bruker teknologien slik den bør brukes: til det beste for pasienter og brukere.

Kanskje bør vi slutte å bruke et teknologisk språk i helsevesenet. Vi snakker om digitalisering når vi jo i utgangspunktet mener smarte måter å forbedre helsevesenet og relasjonen mellom sykepleiere og pasienter på ved å tilby innovative digitale verkt $\varnothing y$.

\section{Nye roller}

Når kommunikasjonsmåter endres, og når pasientene selv kan skaffe seg store mengder informasjon samt utføre selvmonitorering, kan det oppstå en endring i rollene som henholdsvis ekspert og tjenestemottaker. Kanskje kan en slik utvikling støtte empowerment og personsentrert omsorg, og dermed forbedre helsetjenestene?

Kanskje en av endringene den digitale verdenen gir, er at det gamle paradigmet om sykepleierrollen som ekspert kan omdannes til et likeverdig partnerskap mellom sykepleiere og pasienter, forsterket av helseteknologier og internett? 
Dette er ikke nødvendigvis bare positivt eller negativt. Men det vil kreve en stor grad av individuell tilpasning, basert på hver enkelt persons behov. Videre vil nok vi som helsepersonell i større grad måtte tilpasse tjenestene til hver enkelt pasient når teknologien gir nye og større forpliktelser når det gjelder egenomsorg og egenhåndtering, det å skaffe seg kunnskap og informasjon selv samt å iverksette kontakt med helsetjenesten.

\section{Nye kommunikasjonsformer}

Positive aspekter ved skriftlig kommunikasjon, for eksempel via sikre meldinger, er at både pasienter og sykepleiere kan reflektere over og bruke mer tid på å tydeliggjøre sine budskap i kommunikasjonen. Å kommunisere skriftlig skaper tid og rom til å formulere tydelige og gjennomtenkte meldinger på en måte som verbal kommunikasjon ikke muliggjør på samme måte.

Dette kan potensielt forbedre kommunikasjonen fordi det skjerper bruken av ord. Dette er viktig i skriftlig kommunikasjon, men også i journalnotater som skal være tilgjengelige for pasientene.

\section{$\equiv$ ¿Noe vil forsvinne i den skriftlige kommunikasjonen.»}

Likevel vil noe forsvinne i den skriftlige kommunikasjonen, for eksempel spesifikke, non-verbale signaler som $\varnothing$ yekontakt og ansiktsuttrykk. Videokonsultasjoner vil kunne tilby noe mer av dette, men fremmer likevel mindre non-verbal kommunikasjon enn tradisjonelle ansikt-til-ansikt-samtaler.

Derfor må sykepleiere utvikle nye ferdigheter i kommunikasjon og vurderinger når de i økende grad skal tilby helsetjenester i den digitale verdenen. Disse nye kompetansene bygger videre på eksisterende kunnskap og ferdigheter, men de vil kreve tilpasning og endring.

\section{Oppsummering}

Hvordan skal vi så forstå sykepleier-pasient-relasjonen i en digital verden? Forskning og erfaring viser at denne relasjonen er i kontinuerlig endring. Nye måter å tilby sykepleie til pasienter på blir muliggjort, og til dels påkrevd, av vår digitale verden. Dette krever formell forberedelse, opplæring og ny kompetanse, både av sykepleiere og av pasienter. 
Hvordan man mest hensiktsmessig kan bruke digitale verkt $\varnothing \mathrm{y}$ $i$ helsetjenesten, bør ikke antas å være allmenn kompetanse og generell kunnskap i den nåværende arbeidsstyrken i helsetjenesten. Opplæring og utdanning i nye måter å levere helsetjenester på bør starte allerede i sykepleierutdanningen.

Likevel er det ikke tilstrekkelig kun å lære opp fremtidens helsepersonell: Den nåværende arbeidsstyrken bør også kurses når nye systemer tas i bruk. Opplæringen bør fortsette gjennom hele karriereløpet, slik at yrkesutøvere får kompetanse i å tilby sykepleie på nye måter til pasienter og pårørende.

Grundig opplæring vil kunne bidra til å utnytte teknologien på en best mulig måte når det gjelder sykepleier-pasientrelasjonen. Det kan føre til at sykepleiere kan dra nytte av teknologien for å forbedre og støtte pasientsentrert sykepleie og kommunikasjon, i stedet for å begrense det.

\section{$\equiv$ «Det handler ikke om teknologi versus sykepleie og omsorg.»}

Jeg vil legge til følgende bemerkning: Det er viktig å påpeke at digitale helsetjenester ikke er hensiktsmessig for alle pasienter og brukere helt ennå. Vi trenger fortsatt muligheten til å differensiere basert på individuelle ønsker og behov.

I tillegg er det, som tidligere nevnt, ikke nødvendigvis noen motsetning mellom «varme hender» og «kald teknologi». Det handler ikke om teknologi versus sykepleie og omsorg. Det handler om at sykepleiere må ha muligheter til å bruke teknologien på en best mulig måte: for å møte omsorgsbehovet til hver enkelt pasient - nøyaktig det som er hensikten med enhver sykepleier-pasient-relasjon.

Denne fagartikkelen er basert på min prøveforelesning $i$

forbindelse med doktorgradsdisputas $i$ helse og medisin, Det helsevitenskapelige fakultet, Universitetet $i$ Stavanger, 19. oktober 2018.

\section{Referanser}

1. Meld. St. 29 (2012-2013). Morgendagens omsorg. Oslo: Helse- og omsorgsdepartementet; 2013.

2. Meld. St. 26 (2014-2015). Fremtidens primærhelsetjeneste - nærhet og helhet. Oslo: Helse- og omsorgsdepartementet; 2014 . 
3. Meld. St. 27 (2015-2016). Digital agenda for Norge - IKT for en enklere hverdag og $\varnothing \mathrm{kt}$ produktivitet. Oslo: Helse- og omsorgsdepartementet; 2016.

4. Ferwerda M, van Beugen S, van Burik A, van Middendorp $\mathrm{H}$, de Jong EMGJ, van de Kerkhof PCM, et al. What patients think about E-health: patients' perspective on internet-based cognitive behavioral treatment for patients with rheumatoid arthritis and psoriasis. Clinical Rheumatology.

2013;32(6):869-73.

5. Hanlon P, Daines L, Campbell C, McKinstry B, Weller D, Pinnock H. Telehealth interventions to support selfmanagement of long-term conditions: a systematic metareview of diabetes, heart failure, asthma, chronic obstructive pulmonary disease, and cancer. Journal of Medical Internet Research. 2017;19(5):e172.

6. Lie SS. An eHealth intervention based on Guided Selfdetermination program for adults with type 2 diabetes in general practice. Stavanger: Universitetet i Stavanger; 2018.

7. Lie SS, Karlsen B, Graue M, Oftedal B. The influence of an eHealth intervention for adults with type 2 diabetes on the patient-nurse relationship: a qualitative study. Scand J Caring Sci. 2019;33(3):741-49.

8. Barello S, Triberti S, Graffigna G, Libreri C, Serino S, Hibbard J, et al. eHealth for patient engagement: a systematic review. Front Psychol. 2015;6:2013.

9. Elbert JN, van Os-Medendorp H, van Renselaar W, Ekeland GA, Hakkaart-van Roijen L, Raat H, et al.

Effectiveness and cost-effectiveness of eHealth interventions in somatic diseases: a systematic review of systematic reviews and meta-analyses. Journal of Medical Internet Research. 2014;16(4):e110.

10. O'Cathain A, Drabble JS, Foster A, Horspool K, Edwards L, Thomas C, et al. Being human: a qualitative interview study exploring why a telehealth intervention for management of chronic conditions had a modest effect. Journal of Medical Internet Research. 2016;18(6):e163. 
11. O'Connor S, Hanlon P, O'Donnell CA, Garcia S, Glanville $\mathrm{J}$, Mair FS. Understanding factors affecting patient and public engagement and recruitment to digital health interventions: a systematic review of qualitative studies. BMC medical informatics and decision making. 2016;16(1):120.

12. Varsi C, Gammon D, Ruland CM, Wibe T. Patients' reported reasons for non-use of an internet-based patientprovider communication service: qualitative interview study. Journal of Medical Internet Research. 2013;15(11):e246.

13. Vatnøy TK, Thygesen E, Dale B. Telemedicine to support coping resources in home-living patients diagnosed with chronic obstructive pulmonary disease: Patients' experiences. Journal of Telemedicine and Telecare. 2017;23(1):126-32.

14. Lie SS, Karlsen B, Niemiec CP, Graue M, Oftedal B. Written reflection in an eHealth intervention for adults with type 2 diabetes: a qualitative study. Patient preference and adherence. 2018;12:311-20.

15. Lie SS, Karlsen B, Oord ER, Graue M, Oftedal B. Dropout from an eHealth intervention for adults with type 2 diabetes: a qualitative study. Journal of Medical Internet Research. 2017;19(5):e187.

16. Nagel DA, Penner JL. Conceptualizing telehealth in nursing practice: advancing a conceptual model to fill a virtual gap. J Holist Nurs. 2016;34(1):91-104.

17. Strandas M, Bondas T. The nurse-patient relationship as a story of health enhancement in community care: a metaethnography. Journal of Advanced Nursing. 2018;74(1):11-22.

18. Zoffmann V, Hörnsten A, Storbækken S, Graue M, Rasmussen B, Wahl A, et al. Translating person-centered care into practice: a comparative analysis of motivational interviewing, illness-integration support, and guided selfdetermination. Patient education and counseling. 2016;99(3):400-7.

19. Mead N, Bower P. Patient-centredness: a conceptual framework and review of the empirical literature. Soc Sci Med. 2000;51:1087-110.

20. McWilliam C. Patients, persons or partners? Involving those with chronic disease in their care. Chronic Illness. 
21. Greengard S. Living in a digital world. Communications of the ACM. 2011;54(10):17-9.

22. NOU 2011: 11. Innovasjon i omsorg. Oslo: Helse- og omsorgsdepartementet; 2011.

23. van Houwelingen CTM, Moerman AH, Ettema RGA, Kort HSM, Ten Cate O. Competencies required for nursing telehealth activities: a Delphi-study. Nurse Education Today. 2016;39(C):50-62.

24. Pols J, Moser I. Cold technologies versus warm care? On affective and social relations with and through care technologies. Alter - European Journal of Disability research, Revue européen de recherche sur le handicap. 2009;3(2):15978.

25. Grumme SV, Barry DC, Gordon CS, Ray AM. On virtual presence. Advances in Nursing Science. 2016;39(1):48-59. 